\title{
(息)
}

Citation:

Leguina, A and Arancibia-Carvajal, S and Widdop, P (2015) Musical preferences and technologies: Contemporary material and symbolic distinctions criticised. Journal of Consumer Culture. ISSN 1741-2900 DOI: https://doi.org/10.1177/1469540515586870

Link to Leeds Beckett Repository record:

https://eprints.leedsbeckett.ac.uk/id/eprint/1356/

Document Version:

Article (Accepted Version)

Date of Acceptance: 13th April 2015

The aim of the Leeds Beckett Repository is to provide open access to our research, as required by funder policies and permitted by publishers and copyright law.

The Leeds Beckett repository holds a wide range of publications, each of which has been checked for copyright and the relevant embargo period has been applied by the Research Services team.

We operate on a standard take-down policy. If you are the author or publisher of an output and you would like it removed from the repository, please contact us and we will investigate on a case-by-case basis.

Each thesis in the repository has been cleared where necessary by the author for third party copyright. If you would like a thesis to be removed from the repository or believe there is an issue with copyright, please contact us on openaccess@leedsbeckett.ac.uk and we will investigate on a case-by-case basis. 


\section{Musical preferences and technologies: Contemporary material and symbolic distinctions criticised}

Leguina, A., Arancibia-Carvajal, S. and Widdop, P

Journal of Consumer Culture

Version: second revision

\section{Introduction}

Our research is framed on a combination of elements such as cultural taste and consumption, technologies, and practices, providing a theoretical account and empirical evidence of the social stratification of musical practices, as a combination of taste and two aspects of technological engagement: modes of exchange; and formats. Today how individuals interact with various cultural items is not perfectly consistent with theoretical frameworks of influential scholars on cultural consumption, such as Bourdieu (1984), Gans (1999), and Peterson and Simkus (1992). One such variation is in the ever increasing variety of technological modes to acquire and listen to music (Pinch and Bijsterveld, 2004). However, as a consequence of digital divides (van Dijk, 2006), technological items may not be distributed equally among social groups. At present, the value of status-making through a preference for different genres of music extends itself to different forms of consumption and ways of experiencing music. We are yet to fully understand the power these practices have on generating status. This article is therefore motivated by the need to integrate within quantitative frameworks of taste and cultural consumption, an analysis of individuals' technological engagement. These two dimensions, integrated as components of musical practices, enhance our understanding of cultural boundaries across different social groups.

The objective is to bridge a gap detected in the literature, addressing the following questions: Are technological modes to listen to music related to musical tastes? 
Individuals' cultural preferences draw symbolic boundaries (Bourdieu, 1984; Lamont, 1992), reflecting personal and social differences. In common with musical preferences, modes of musical exchange and formats to listen to music are related to individuals' locations within social structures (Lopez-Sintas, Cebollada, Filimon and Gharhaman, 2014). Surprisingly, little has been said about this relationship and its strength. In this regard, theory of practices provides the link to simultaneously analyse taste and technologies (Warde, 2005, 2014). Therefore, as second and third research questions, we ask: How strong is the association between musical technologies and social stratification axes? Does the strength of this relationship surpass that of the relationship between musical taste and social stratification? Salient technological forms of consumption modify listeners and listening practices and cultural rankings (Wright, 2011). Indeed, several authors have noted the way individuals interact with culture could be today a more important status marker than selection of specific cultural objects (Tampubolon, 2008; Prieur and Savage, 2013; Lopez-Sintas et al, 2014). In this regard, we do not yet know the value that alongside taste, technological engagement has as a form of distinction.

This study provides an analysis of musical tastes and technologies in Chile, the first time such analysis has been carried out. In 40 years and based on one of the most open market economies in the world, Chile has been transformed from one of the poorest to one of the fastest growing and economically stable countries in Latin America, but at the same time is the OECD state member with the highest income inequality (ECLAC, 2011; OECD, 2013). Indicators of musical taste and technologies, operationalized as methods of exchange (ranging from buy on streets to free Internet downloads) and technological formats and devices (from radio stations to portable digital reproducers) to listen to music, are analysed through a multiple factor analysis (MFA), an extension of multiple correspondence analysis (MCA). This is an update to the statistical method commonly preferred for this type of analysis (Leguina, 2015) which overcomes some of 
MCA pitfalls in cases where researchers are interested in comparing the contribution of different groups of variables (Escofier and Pages, 1994). Our analysis expects to provide an extra layer of information on the relationship between musical practices and social structures, elucidating how music consumption practices interact with cultural boundaries.

\section{Cultural and technological stratification}

Despite being constantly revisited and criticized, Bourdieu's seminal work Distinction (Bourdieu, 1984), continues to attract the attention of cultural sociologists around the world with an interest in understanding the way in which individuals' cultural practices are used to draw, reinforce or cross symbolic (cultural) boundaries (Bennett, 2011; Prior, 2013; Lizardo and Skiles, 2012). According to the Bourdieusian framework, the judgment of what is good or bad taste, or habitus, closely relates social structure and aesthetic preferences. Habitus is defined by Bourdieu as reproduced and inherited dispositions that generate the capacity to produce judgment and action. Furthermore, during the life-course different types of capitals are accumulated. Four basic forms of capitals (economic, cultural, social and symbolic) are species of interchangeable power that allow individuals to obtain certain profits. Homology implies that cultural taste (cultural capital) is socially structured from a position of domination and symbolic violence, where members of the higher classes tend to prefer more sophisticated, 'difficult' art forms and a rejection of popular culture, while the middle classes (or petit bourgeoisie) aspire to and imitate the tastes of dominant groups, while simultaneously struggling to differentiate themselves from the dominated working classes. These struggles for different social positions take place in fields, which are systems of relations where individuals display and exchange their resources to access advantaged positions.

An important aspect of cultural consumption is the ranking of cultural items. To verify whether individuals' tastes delimitate or cross boundaries, these have to be defined 
according to a hierarchy. This normally assumes that some pieces of art are recognised as being of high aesthetic value - good taste - provided by dominant institutions and individuals with the highest levels of cultural capital. Any hierarchical system however faces difficulties with diversification of cultural items. Among the many criticisms to Bourdieu's thesis, and there are many, it is relevant for our research to highlight the assumption that tastes of socially advantaged individuals always imply highbrow cultural items (Warde, 2011). An individual's taste however might not be consistent across fields and practices. In this regard, the work of Peterson and colleagues showed to be particularly influential (Peterson and Simkus, 1992; Peterson, 2005). The authors argue that cultural distinctions no longer display a high-to-lowbrow hierarchy but an opposition between individuals simultaneously preferring several highbrow and lowbrow musical genres (omnivores), and preferring one or few lowbrow genres (univores) (Peterson, 2005).

A further critique that we must consider is the fact that the Bourdieusian framework neither gives particular attention, nor concedes positive significance to lowbrow culture. The denial of popular culture is seen in the little emphasis that the author gives to phenomena such as commercial systems, music-based youth groups and subcultures, and changes in cultural hierarchies (Prior, 2013). Additionally, and probably due to the reduced importance they had in his time, there is no special focus on technologies to acquire music. The choice for the necessary is how Bourdieu (1984) defines cultural consumption of the lower classes, and it is best understood as the expression of class habitus rooted in the lives of the working-class. Bennett (2011) believes that this prevented Bourdieu from giving positive meaning to their cultural activities, denying the working-class any ability to make aesthetic judgments. Frith (1996) claims that knowledge in popular music can also be an expression of superiority, just as classical music is. In fact, the detailed study of Bennett et al (2009) in the UK shows that classical music is not the field where biggest struggles amongst position-takers take 
place, but it is in popular music where the major disputes and tensions are most noticeable.

Several authors argue that extracted results and conclusions derived from most quantitative research inspired on Bourdieu's framework, especially when analysing survey data about cultural preferences, have limited scope (Holt, 1997, 1998; Lizardo, 2008; Daenekindt and Roose, 2014). These kinds of indicators, referred to as objectified taste (Holt, 1997), lead us to commonly assume that the way of listening to music constitutes an inherent characteristic of individuals. Indeed, it is recognized in the importance of quantifying differentiated styles of consuming, namely embodied tastes (Holt, 1997). In this regard, technological advancements are constantly changing the way individuals think, feel, and adopt them (Lehtonen, 2003), and more generally the Internet and information and communication technologies (ICTs) play an important role on people's lives (Castells, 2001). Devices and networks are indeed accessible to an increasingly large number of people, however as noted by some commentators, there are growing digital divides in terms of attitudinal aspects about technology usage; and not just the number of people with access to these technologies. As a result of these conceptualizations, digital divides have been detected not only between individuals' social positions, but across age, gender, ethnicity, and other sociodemographics (Attewell, 2001; van Dijk, 2006, 2008; Tsatsou, 2011).

If both, musical taste and use of technologies, are socially stratified, are specific musical preferences associated to specific technologies used to access to them? Alternatives available to access and consume music are more heterogeneous than ever. Music can be listened through a digital device (computer, MP3 player, mobile phone), physical format (vinyl, $\mathrm{CD}$, cassette), free on radio stations or simultaneously watched through video clips, performances on TV shows or live concerts. As noted by DiMaggio (1987), as people are becoming technologically more advanced they become more mobile and 
live in many overlapping social worlds, which are now both online and offline. This has implications for those not technologically mobile. Technologies facilitate access, on the one hand, to non-highbrow culture that many would not normally engage in because of the feeling of embarrassment, and on the other to a broader range of activities to disadvantaged social groups (Lahire, 2008). At the same time, digital divides might collaborate on accentuate musical distinctions, limiting access to music forms exclusively available under certain formats. As with taste, technologies imply different practices generated from not only social differentiation and habitus, but also in attitudes, motivation, practical competence, and involvement (Sterne, 2003a). In this article we therefore provide a theoretical account and empirical evidence about the simultaneous cultural stratifications of musical taste and technologies.

\section{Technologies and musical practices}

Musical technologies offer consumers a great number of aesthetic alternatives. Some suggest that consequences of this phenomenon are shifting socialization scenarios into new technological contexts and the blurring of cultural boundaries (Peterson, 2005; Wright, 2011). New forms to consume cultural items allow individuals to engage predominantly in private, changing structures of cultural rankings (Lahire, 2008). Additionally, as Magaudda (2011) argues, technological advancement on digital music produce a reconfiguration on the relationship between materiality and culture, playing an essential role on consumers practices. Several authors from different traditions such as social history, science, technology and society studies (STS), musicology, and sound studies recognize that to understand the social dimensions of music and its consumption, is necessary to focus on practices and relevant actors, as well as technical and material dimensions (Sterne, 2003b; Pinch and Bijsterveld, 2004; Magaudda, 2014). They have made strenuous efforts to understand the relationship between different music technologies and sociocultural formations, documenting the origins and evolution of sound reproduction technologies ranging from socio-historical accounts of the early 
days (Sterne, 2003b; Taylor, Katz and Grajeda, 2012), the historical and cultural context of radio broadcasting (Crisell, 2002, 2003), the development of the Mogg synthesiser (Pinch and Trocco, 2002), and the evolution of the MP3 as music format (Sterne, 2012) to more specific social phenomenon such as the genderisation of hi-fi systems in American postwar households (Keightley, 1996), the vinyl and its persistence on the market (Bartmanski and Woodward, 2013), personal stereos in the everyday life (Bull, 2000), and the iPod and its usages (Bull, 2013; Prior, 2014).

A theoretical framework commonly adopted by research in the subject, including some of previously cited research, is theory of practices (Schatzki, 1996; Reckwitz, 2002; Warde, 2005), and its connection to STS perspectives (Magaudda, 2011; Warde, 2014). In our case, to integrate the technological dimension to musical taste, Warde (2005) is a particularly pertinent source that introduces relevant concepts from theory of practices to cultural consumption. According to the author, cultural taste does not imply practice by itself because it is a moment of almost every practice and it is engagement in different practices that explains the nature and process of consumption. Individuals are carriers of practices in the form of bodily behaviour and routinized ways of understanding, knowing how and desiring. Taste, and technologies are embedded in consumption practices; they cannot be separated from their uses and functions, and grounded in social networks of individuals. Whilst not a new concept, this does open the debate for considering different forms of cultural distinctions, based on not considering tastes or technologies subjugated to the other.

To date however, quantitative research on cultural consumption that integrates dimensions of musical practices beyond objectified taste is rather limited. Traditionally, research integrates indicators of musical knowledge (Erickson, 1996; Savage and Gayo, 2011) or differentiates between the consumption of recorded music and the act of attending a live concert (for instance, Chan and Goldthorpe, 2007; Tampubolon, 2008; 
Roose and Stichele, 2010). Taking a different approach, Rössel (2011) analyses modes of listening to opera during live performances (individuals' engagement with and experience of music), conceptualizing them as indicators of analytical and cognitive mastery and states of aesthetic pleasure. Regarding to research that integrates technologies, some present a detailed description of practices for accessing music using digital technologies (Lopez-Sintas, Zerva and Garcia-Alvarez, 2012; Lopez-Sintas et al, 2014) and methods of learning about new music (Tepper and Hargittai, 2009). The research performed by Lopez-Sintas, Garcia-Alvarez and Filimon (2008) is unique in this respect; they focus on patterns of musical preferences and their relationship with purchases, collections of CDs, and technologies which people use. Their results show tension in socioeconomic terms between advantaged consumers who prefer highbrow (sometimes alongside lowbrow) music that acquire CDs frequently (through several channels and using several technologies) and socially disadvantaged consumers with more restricted preferences, methods and collections.

In summary, we argue that research on cultural and social stratification should not only emphasize how social differences are shaped around personal taste judgements, but must also not forget how culture is acquired and shared. Listeners and music fans find pleasure in diverse forms such as knowledge accumulation, live experiences, or collection of artefacts, aspects that may not have power outside musical domains that define its symbolic existence (Crossley and Bottero, 2014). Moreover, when there is no fear of disapproval and negative judgment, Lahire (2008) questions, what happens to cultural norms? We do not know the value that selected technologies have on different forms of distinction.

In this regard our analysis proposes to integrate taste and technologies as a whole part of consumption practices. To address our research questions, we give special emphasis to the study of two dimensions of musical technologies: 'musical exchange' and 'musical 
formats.' Although these cover different consumption practices, they can be roughly grouped all together under the umbrella of 'technologies' and is a way to identify potential differences between how music is acquired and how it is actually listened. The former refers to 'how individuals nowadays get into music, either of which can be market or social exchanges' (Lopez-Sintas et al, 2014: 56-7). Here we cover aspects which might imply or not technological involvement such as buying music in stores or acquiring it through gifts, free Internet downloads, and informal markets (Tepper and Hargittai, 2009; Sezneva, 2012; Bustinza, Vendrell-Herrero, Parry and Myrthianos, 2013). For the latter, we recall Sterne's (2012) definition of format, which 'denotes a whole range of decisions that affect the look, feel, experience, and workings of a medium. It also names a set of rules according to which a technology can operate' (Sterne, 2012: 7). This is particularly useful to capture differences between analogue and digital modes to listen to music, especially relevant after major changes to the music industry since the late 1990s (Hesmondhalgh, 2009; Wright, 2011).

\section{Chile: material and symbolic differences}

Thanks to the increasing availability of data to extend research beyond western societies, studies in the area of culture and social stratification have reached great popularity. This study is part of this tradition and provides an analysis of musical tastes and ways to access music in Chile, the first time such analysis has been carried out. Over the last 40 years the country has experienced several economic transformations, both as a result of international contingencies and prevailing internal policies. These have derived in changes in the economy; from a relatively closed state controlled model during the $60 \mathrm{~s}$, to one of the most open economies in the mid to late $90 \mathrm{~s}$, with a decreasing state influence in production and regulation. From being one of the poorest countries in Latin America, Chile currently ranks as one of the richest in the subcontinent. The poverty rate, which reached levels above $40 \%$ in 1987 , was reduced to close to $20 \%$ in 1996 (French-Davis, 1999). Despite sustained growth, income 
distribution does not appear to have been significantly altered; and today, Chile is the most unequal among the OECD members (OECD, 2013), with a population that is also extremely centralized around the capital (Santiago) which contains $40 \%$ of the national total population (INE, 2002). Socioeconomic differences have a noticeable impact on many dimensions of an individuals' life, and ICTs are no an exception. According to the National Institute of Statistics, household Internet access reaches only 62\% (12\% below OECD members average), and unlike all other OECD countries, in Chile Internet is accessed mainly from educational institutions or workplaces, rather than households.

For music consumption, according to the 3rd National survey of cultural participation and consumption performed by the Consejo Nacional de la Cultural y las Artes (2012) among the usual means of listening to music, the most popular is radio stations $(43.1 \%)$. In the country it is possible to find $180 \mathrm{AM}$ and 64 FM stations (NationMaster, 2014). The second and third media usages are CDs or DVDs (25.5\%), followed by the digital files $(25.1 \%)$. It should be noted that piracy is popular activity among Chileans; $20.8 \%$ declared purchasing their records from street vendors. According to a study by the Business Software Alliance, Chile is the third highest consumer of illegal software, with $59 \%$ of total consumption, just behind Turkey $(60 \%)$ and Greece, which tops the list (62\%) (Viollier, 2013). Illegal Internet downloads also provides an important access to music, with $28.6 \%$ of the total population declaring that they download music for free online.

The Chilean musical domain has historically been formed through various expressions that mix folk traditions related to life conditions on countryside in the centre and south, subsequent migration to big cities (cueca), and the different sounds found in the north Andean region of the country (andina) and different Latin-American roots (Gonzalez, 2011). In this regard, Mexican music (ranchera) from the early twentieth century has been immensely popular for the working-class rural population in the south of the 
country (Mularski, 2012). Foreign genres from Latin America such as salsa, cumbia and sound (often grouped as tropical), Cuban bolero, Argentinian tango, and Puerto Rican reggaeton have been largely included in the local urban music mainstream (Rivera, 2011; Gonzalez, 2011; Karmy, 2013). As any culturally open country, romantic ballads, pop, rock and classical music from Europe and the USA, are not only popular but form new mixed and hybrid styles (Gonzalez, 2011). In fact, according to NSCPC data, $47.7 \%$ of the populate prefer Latin American music, while 24.2\% national music; only $13.7 \%$ and $7.3 \%$ noted tastes for music from USA and Europe respectively. These political, economic and cultural features go some way in explaining the symbolic differentiation in Chile, reflected by several patterns of cultural consumption previously detected in the literature (Torche, 2007, 2010; Gayo, Teitelboim and Mendez, 2009). Chile is a melting pot of different musical genres and tastes; furthermore given its complex relationship with means of acquiring music and its economic disparity, it makes an excellent test bed for exploring research questions of this article.

\section{Research questions and hypotheses}

Different forms of consumption have the potential to modify practices and re-structure cultural classification rituals. However, we do not know the value that selected ways of acquiring music have as forms of distinction (Prieur and Savage, 2013; Crossley and Bottero, 2014). Similarly to the process of taste, chosen musical modes of exchanges and formats are not only related to habitus and social structures, but also to other factors such as necessity, favouritism, and competences (Sterne, 2003a; Warde, 2005; Lahire, 2008). As a consequence our first research question (RQ1) is laid out as follows: Are technological modes used to listen to music related to musical tastes? We expect to observe positive association between some combinations of taste and technological modes of access to music. Furthermore, we hypothesize that these dimensions of cultural practices are part of cultural hierarchies and they shape forms of distinction that are as of yet, to be conceptualized, for example free-paid and technological advanced- 
not advanced. These are found in correlation with different demographic characteristics, but mainly with age, education and social class (Tepper and Hargittai, 2009; LopezSintas, Garcia-Alvarez and Filimon, 2008; Lopez-Sintas et al, 2014).

According to some scholars in the field, the way people interact with culture could be more important today than preference for certain cultural items (Warde, 2005; Tampubolon, 2008; Magaudda, 2011; Prieur and Savage, 2013). However, the association between musical taste and technologies, and its joint ability to draw symbolic boundaries across social groups has not been empirically quantified. Therefore our second and third research questions read (RQ2): How strong is the association between musical technologies and social stratification axes? (RQ3): Does the strength of the relationship between technologies and social stratification superexceed that between musical taste and social stratification axes? Simultaneously analysing various dimensions of cultural consumption practices, it is expected that in Chile, a society where material differences are still important, technologies delimit cultural bounds at least as strong as taste. Additionally, we expect to find some degree of consistency between distinctions that taste, musical exchanges, and formats are able to reflect, especially related to differences between age cohorts and those in different social classes.

\section{Data and method}

\section{Data}

This article draws on Chilean data from '3rd National survey of cultural participation and consumption' (Consejo Nacional de la Cultural y las Artes, 2012). The survey was conducted during the 2012, to 8,200 men and women over 15 years old belonging to urban areas from the 15 regions of the country, with a national sampling error of $1.08 \%$. They were asked about 26 different areas of cultural consumption. After excluding from the analysis people under aged (15-17 years) and people that do not listen to music, the effective sample size to analyse is 7,530 individuals. 
Table Error! No text of specified style in document..1. Descriptive statistics of sociodemographic variables.

\begin{tabular}{|c|c|c|c|c|c|c|}
\hline \multicolumn{6}{|c|}{ Sociodemographic variables $(\%)$} & \multirow{3}{*}{$\begin{array}{c}\text { Missing } \\
0 \\
0\end{array}$} \\
\hline \multirow{2}{*}{ Age (in years) } & $18-29$ & $30-44$ & $45-59$ & $>=60$ & & \\
\hline & 19.3 & 25.6 & 28.6 & 26.5 & & \\
\hline \multirow{2}{*}{ Sex } & Female & Male & & & & \\
\hline & 54.4 & 45.6 & & & & 0 \\
\hline \multirow{2}{*}{ Ethnic group } & Yes & No & & & & \\
\hline & 10.5 & 89.5 & & & & 0 \\
\hline \multirow{2}{*}{ Education } & No/Basic & Sec. inc. & Sec.comp. & Ter. inc. & Ter. comp. & \\
\hline & 25.6 & 15.1 & 36.1 & 9.1 & 14.1 & 0 \\
\hline \multirow{2}{*}{$\begin{array}{l}\text { Income (in } \\
\text { thousands) }\end{array}$} & $<=\$ 245$ & $\$ 245-\$ 440$ & $\$ 440-\$ 670$ & $>=\$ 670$ & & \\
\hline & 27.2 & 27.6 & 18.5 & 23.4 & & 3.3 \\
\hline \multirow{2}{*}{$\begin{array}{l}\text { Socdem. } \\
\text { group }\end{array}$} & Lower & Lower middle & Middle & Upper middle & Upper & \\
\hline & 16.9 & 36.7 & 19.7 & 16.1 & 6.6 & 4.0 \\
\hline \multirow{2}{*}{$\begin{array}{l}\text { Place of } \\
\text { residence }\end{array}$} & North & Centre & South & $\begin{array}{c}\text { Metropolitan } \\
\text { (Santiago) }\end{array}$ & & \\
\hline & 30.6 & 27.1 & 30.0 & 12.3 & & 0 \\
\hline
\end{tabular}

\section{Sociodemographic variables}

Some of the most frequently analysed sociodemographic variables in the literature were included in the analyses (table 5.1 provides descriptive statistics). Age was codified on four categories to broadly illustrate tension among young-middle-older age groups. Sex (female-male) is treated as categorical. A dichotomic variable indicates respondents' self-declared belonging to any ethnic group. Educational level is divided on five categories. Secondary and tertiary were subdivided as complete or incomplete. Household net income (pesos per month) is divided into four categories. As proxy of occupational class, we use individuals' socioeconomic groups, based on a combination of household educational level, house characteristics and possession of several items, characterization which especially distinguishes gaps between lower middle and lower segments (Asociación de Investigadores de Mercado, 2013). To retain the peculiar distribution of Chilean social groups, we retain the original classification: lower (E), lower middle (D), middle (C3) and upper/upper middle $(\mathrm{ABC} 1+\mathrm{C} 2)$. For place of residence, we include a variable that describes the region where respondents are located. 
Table Error! No text of specified style in document..2. Musical taste indicators.

\begin{tabular}{ccccc}
\hline Genres & 1st & 2nd & 3rd & $\begin{array}{c}\text { Mentioned } \\
\text { any order }\end{array}$ \\
\hline Romantic ballad $^{\text {Preference (\%) }}$ & 23.9 & 16.8 & 8.6 & 49.3 \\
Tropical $^{1}$ & 6.9 & 12.4 & 10.7 & 30.0 \\
Folk & 7.0 & 9.0 & 12.5 & 28.5 \\
Bolero & 13.3 & 7.8 & 4.9 & 26.0 \\
Mexican & 9.6 & 8.6 & 5.0 & 23.2 \\
Pop & 7.1 & 6.5 & 3.8 & 17.4 \\
Rock & 9.5 & 4.5 & 2.4 & 16.4 \\
Classical & 6.3 & 4.6 & 3.0 & 13.9 \\
Reggaeton & 3.4 & 3.9 & 3.4 & 10.7 \\
Tango & 1.7 & 4.1 & 2.9 & 8.7 \\
Electronic & 1.4 & 2.0 & 3.4 & 6.8 \\
Fussion $^{2}$ & 1.4 & 2.4 & 2.7 & 6.5 \\
Hip hop & 1.5 & 1.8 & 1.5 & 4.8 \\
Heavy metal & 1.2 & 1.4 & 0.6 & 3.2 \\
\hline
\end{tabular}

1: Includes salsa, merengue, cumbia and sound; 2: Includes jazz, bossa nova, soul and blues.

\section{Taste and technology variables}

Regarding indicators of musical taste, respondents reported on up to three most favourite genres selected from a list of fourteen options. This list adequately covers the previously described characteristics of the Chilean musical scene. Table 5.2 presents the genres sorted by their popularity level defined as the total percentage of individuals who claim to prefer them regardless of their order. To take into account the range of tastes that individuals have, it has been decided to keep the order. Given the structure of the questions about musical tastes, it is not possible to consider in our analysis aspects as dislikes or more detailed measures regarding cultural omnivourism.

Table 5.3 presents a summary of variables related to musical technologies available. One question asks about the most frequent method of 'exchange.' To facilitate the analysis, it was decided to merge several categories. The category 'borrow' (5.2\%) were merged with gifts. Two questions add information about the most frequently used format and device to listen to music. In the case of formats, due to low frequency, 
cassettes $(1.0 \%)$ was merged to $\mathrm{CD} / \mathrm{DVD}$, and on the category 'other formats', music television networks $(2.5 \%)$ and vinyl $(0.3 \%)$ were included. Regarding devices, record player $(0.4 \%)$ and walkman $(0.1 \%)$ were merged to 'other' category. Format and device variables included in the survey are highly related. Indeed borders between them have been blurred over time, with devices that constraint or open format choices (Sterne, 2012). To retain as much information as possible about technological engagement, we therefore decided to group them under the previously defined label of 'formats.'

Table Error! No text of specified style in document..3. Frequencies for acquisition and technology usage variables.

\begin{tabular}{|c|c|c|c|c|c|c|c|}
\hline \multicolumn{7}{|c|}{ Music acquisition and technology usage variables ( $\%$ most frequent) } & Missing \\
\hline \multirow{2}{*}{$\begin{array}{l}\text { Methods of } \\
\text { acquisition }\end{array}$} & Don't have & $\begin{array}{l}\text { Borrow or } \\
\text { gifts }\end{array}$ & $\begin{array}{c}\text { Buy on } \\
\text { street }\end{array}$ & Copies & $\begin{array}{c}\text { Free } \\
\text { Internet }\end{array}$ & $\begin{array}{c}\text { Buy on } \\
\text { stores }\end{array}$ & \\
\hline & 12.6 & 18.1 & 18.4 & 2.6 & 21.8 & 26.5 & 0.0 \\
\hline \multirow{2}{*}{ Format } & $\begin{array}{c}\text { Radio } \\
\text { stations }\end{array}$ & $\begin{array}{c}C D / D V D / \\
\text { Cassette }\end{array}$ & $\begin{array}{l}\text { Digital } \\
\text { format }\end{array}$ & Other & & & \\
\hline & 48.1 & 28.3 & 19.1 & 4.2 & & & 0.3 \\
\hline \multirow[t]{2}{*}{ Devices } & $\begin{array}{c}\text { Radiol } \\
\text { Boombox/ } \\
\text { HiFi }\end{array}$ & Computer & Cell phone & $\begin{array}{c}\text { MP3-4/ } \\
\text { iPod }\end{array}$ & Other & & \\
\hline & 75.4 & 10.4 & 8.0 & 4.1 & 1.9 & & 0.2 \\
\hline
\end{tabular}

\section{Analytical strategy: Multiple factor analysis}

Multiple correspondence analysis (MCA) is one of the most commonly used techniques to study the relationship between culture and social stratification (Bennett et al, 2009). Bourdieu himself argued that quantitative analysis tools in sociology must be multidimensional, relational, and should not reduce variable interrelations into dependent-independent hierarchies (Lebaron, 2010). MCA is a multivariate technique used to analyse categorical data, structured as Individuals $x$ Variables tables. Summary values, plotted as clouds, aid to visualise interrelations among variables and individuals. 
Typically, an MCA solution is derived from one set of variables, called active, and a second set could additionally be included as supplementary, which is not part of dimension reduction, but included to complement interpretations. To study the impact of groups of variables on the overall solution, a common practice is to sum the contribution (per cent) of each set of variables to total variance explained by each dimension. However, the influence of each set of variables strongly dependent on the number of variables and categories that each group has. In our case this is especially important as our active variables are divided into three heavily unbalanced groups: 'taste' (14 variables, 3 categories each), 'formats' ( 2 variables, 4 and 5 categories each), and 'exchange' (1 variable with 6 categories).

While we acknowledge conceptual and analytical advantages that MCA has for the study of cultural stratification, we believe it is not the only alternative to perform what those from the Bourdieusian tradition call field analysis (Savage and Silva, 2013). This method, except from rare occasions, has been the orthodoxy for the last 40 years. Therefore, we substitute a regular MCA, in favour of a multiple factor analysis (MFA). The MFA method, an extension of MCA, proposed by Escofier and Pages (1994), allows analysing indicators structured in groups, weighting them to prevent a group having dominant influence in the first dimension, thus allowing a more precise comparison of their contributions within the overall solution. This is performed on two stages. Firstly, consider $j=1, \ldots J$ groups of variables, with $k_{j}$ variables each, that divides the total number of variables, K. Then, to each Variables $x$ Individuals contingency table $\left(Y_{j}\right)$ is applied a MCA and first eigenvalues of each $Y_{j}$ are retained $\left(\lambda_{1}^{j}\right)$ to be used to weight each group of variables. Secondly, MCA to the new matrix $\mathbf{Y}$, product of merge weighted tables, is performed:

$$
\mathbf{Y}=\left[\begin{array}{lll}
\frac{1}{\lambda_{1}^{\mathrm{j}}} & \mathrm{Y}^{1}, \ldots, & \frac{1}{\lambda_{\mathrm{I}}^{\mathrm{j}}} \mathrm{Y}^{\mathrm{I}}
\end{array}\right]
$$


Consequently, using MFA it is possible to quantify groups' weighted contribution and graphically visualize overall answer patterns. Akin to MCA, groups of variables can also be defined as supplementary. This is performed using the package FactoMineR (Lê, Josse and Husson, 2008), part of the R statistical software (R Core Team, 2013). After performing preliminary analyses including missing values as an extra category and excluding them, their reduced amount and lower impact on results lead us to exclude them from final analysis.

\section{Results}

MFA allows us to provide a snapshot of individuals' musical tastes and technologies, breaking down more precisely contributions of each group of variables, balancing them according to the number of variables and categories that compose them, and plotting everything on a highly intuitive map where distance between categories represents the degree of their association. Initially we found that the percentages of variance show that taste, musical exchanges and formats are indeed important components of the Chilean cultural map (table 5.4).

On the first axis, which retains $18 \%$ of the modified total variance, the three sets of variables contribute approximately one-third of its construction. However, from axis 2 to 5 (which holds between $6.3 \%$ and $5 \%$ of the modified total variance) importance of musical exchanges increases. It is only in the sixth axis that the importance of musical formats and taste is revealed. Due to scarcity of space, here we only develop detailed interpretation for the first three axes, retaining $30.2 \%$ of the total variance of the data. The first axis (horizontal), to which contribution to its variance is $36.1 \%$ from formats indicators, $32.1 \%$ from taste, and $31.8 \%$ from exchanges, substantively differs from the second (vertical), for which methods of acquisition contributes the majority of its variance $(76.6 \%)$ (table 5.4). To facilitate our understanding, we simultaneously interpret the first and second axes, dividing figure 6.1 on four quadrants. 
Table Error! No text of specified style in document..4. Results from MFA.

\begin{tabular}{cccccccc}
\hline & Axis & $\mathbf{1}$ & $\mathbf{2}$ & $\mathbf{3}$ & $\mathbf{4}$ & $\mathbf{5}$ & $\mathbf{6}$ \\
\hline \multirow{3}{*}{ Variance } & Eigenvalue & 1.875 & 1.129 & 1.083 & 1.011 & 1.007 & 0.752 \\
& \% retained & 6.2 & 3.7 & 3.6 & 3.3 & 3.3 & 2.5 \\
& \% mod. retained & 18.0 & 6.3 & 5.8 & 5.0 & 5.0 & 2.7 \\
& Cumulated \% & 18.0 & 24.3 & 30.2 & 35.2 & 40.2 & 42.9 \\
\hline \multirow{3}{*}{ Contribution } & Taste & 32.1 & 7.8 & 17.3 & 2.4 & 1.2 & 56.0 \\
& Methods & 31.8 & 76.6 & 79.9 & 97.3 & 98.5 & 4.7 \\
& Technologies & 36.1 & 15.5 & 2.8 & 0.3 & 0.3 & 39.2 \\
\hline
\end{tabular}

The first quadrant (upper right), groups individuals who predominantly use digital formats and devices such as cell phone, computer and MP3/4 player. Their tastes are hip-hop, reggaeton, electronic and pop (as a third option), and the most common way of acquiring music is copying. In sociodemographic terms, individuals in this quadrant are mainly young (18-29 years), with incomplete post-secondary education (unfinished diploma or university degree). Individuals positioned in the second quadrant (lower right) are also characterized by listening to music via computer and MP3/4 player, but they are more likely to use physical formats (CD/DVD/cassette). Perhaps this group see value and a sense of identity by having tangible formats of the music, but also active in embracing emerging structures of technology. Individuals located here have musical preferences based on fusion, pop, rock, heavy rock and classical music as a third option. Their musical exchanges tend more often to be copying or buying in shops. Similar to the first quadrant, they are young and young adults (20-44 years) with complete tertiary education with income over $\$ 670,000$ and belonging to higher socioeconomic groups $(\mathrm{ABC} 1-\mathrm{C} 2)$.

Individuals from the third quadrant (lower left) use mainly CD/DVD/cassette and radios to listen to music. Their musical tastes consist of classical, folk, romantic ballad, and tango as a third option, purchased in stores, but also prone to acquiring this from the 
street. Concerning demographic variables, individuals who prefer classical music share similarities with the second quadrant, while individuals preferring folk and ballads as first choice are adults aged 45-59 with secondary education. Although the nature of taste measures does not allow us to test more elaborated measures of omnivourism, dissonance and other tolerant types (Lahire, 2008; Leguina, 2015), it is between quadrants two and three where we find not only the socially advantaged individuals, but also those who seem to prefer a greater variety of musical genres, being able to mix classical and fusion with rock, pop and romantic ballads. Besides buying in stores, they are not characterized by the selection of more specific exchange methods and formats to listen to music. Finally, the fourth quadrant (upper left) primarily concentrates individuals who listen to music through the medium of radio. Their tastes are mainly based on tastes most aligned to the working classes, namely Mexican, tropical, bolero and tango. These individuals claim not to acquire or possess music, but if they do, they are through loans and gifts or from buying it from street vendors. They belong to the poorest social group (E), with lower education (no/basic), lower income $(<\$ 245,000)$ and older age $(+60)$. 


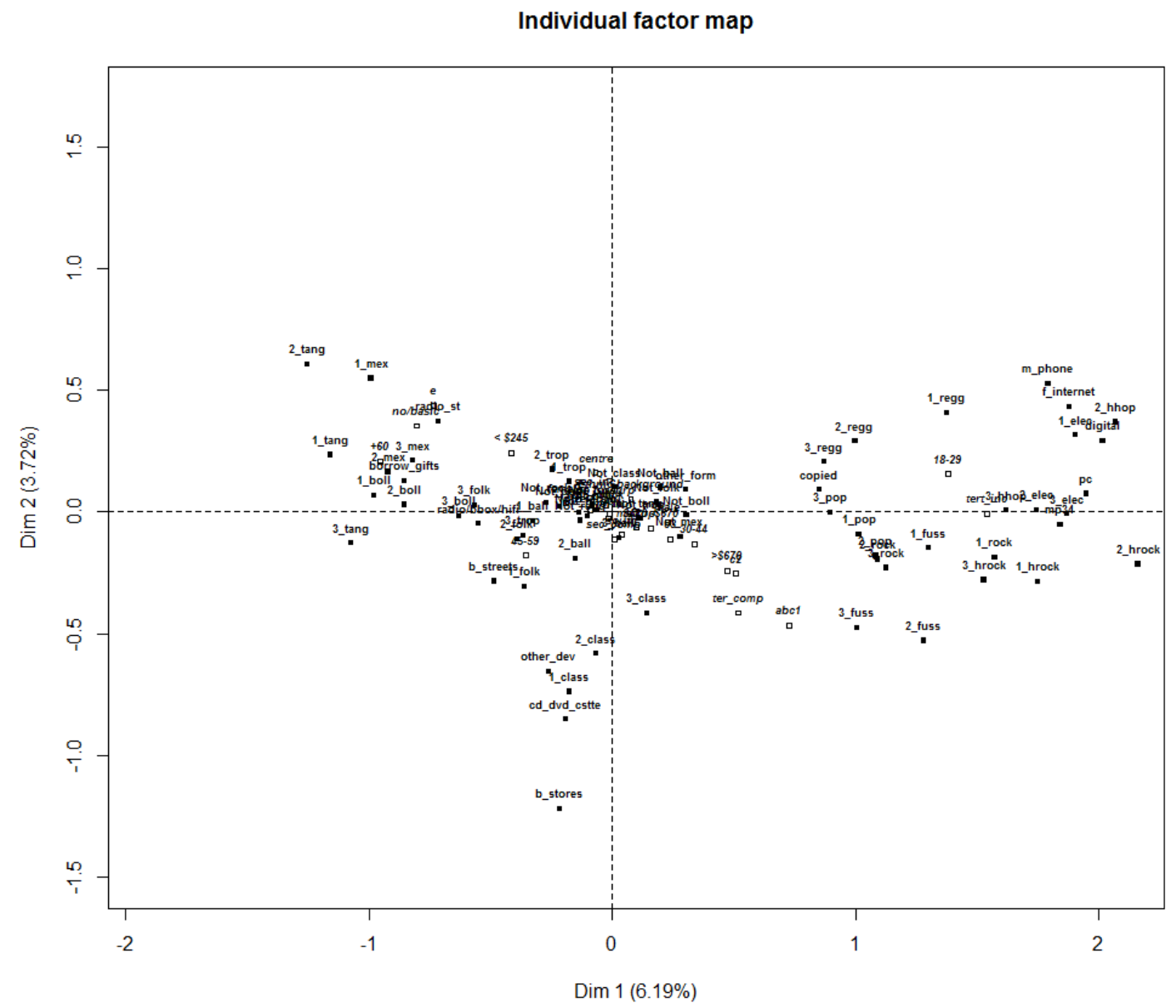

Figure Error! No text of specified style in document..1. MFA overall results for first and second axes.

Third axis variance is predominantly accounted for by methods of acquisition (79.9\%), reaffirming our results described above. Individuals who claim to prefer hip-hop and reggaeton, tend to acquire music mainly through copying and downloading it from the Internet and consuming it through a cell phone. Those who prefer rock, heavy rock, pop, and fusion also use the Internet, but additionally buy music in stores, and most frequently use PC and digital formats. Classical music and folk listeners also acquire it in stores and through borrows and gifts, while those who prefer tango, Mexican and tropical music, listen to the radios, and might acquire music through loans, gifts or 
purchased on the street. This indicates that technologies are not necessarily defining new boundaries but reinforcing those that already exist. Cultural boundaries extracted from our analysis reveal they are structured by both symbolic and material aspects.

As noted throughout this article, the inclusion of technological engagement through exchanges and formats allow us to detect different forms of distinction. In this regard,

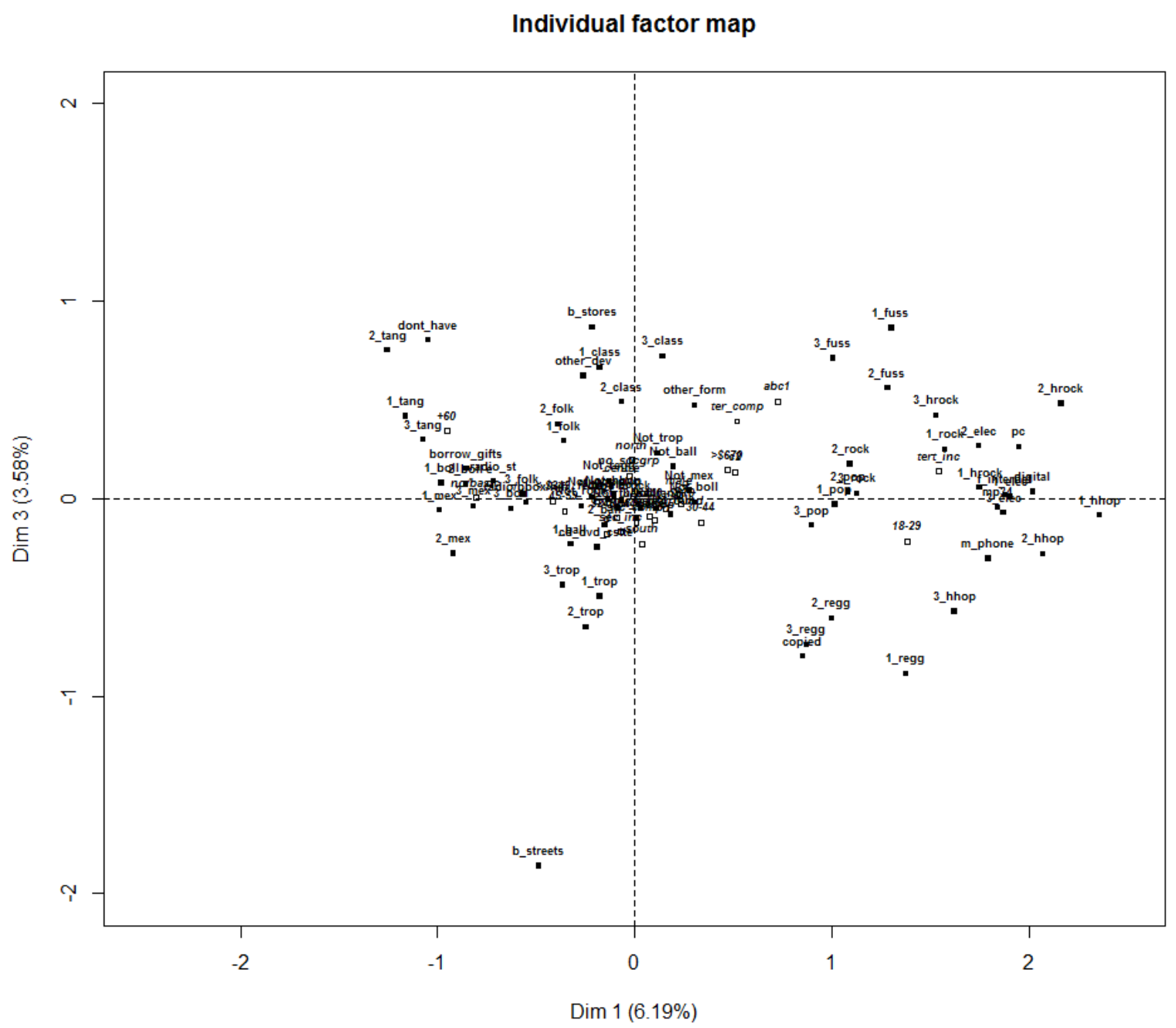

Figure Error! No text of specified style in document..2. MFA overall results for first and third axes. 
we observe how different types of material distinctions, or digital divides, are identifiable. Indeed, it is clear that technological distinctions are correlated to specific taste patterns and social groups. The first axis of MFA reflects not only tension between music preferred by young age groups (hip-hop, reggaeton, rock and heavy rock) and adults (tango, Mexican, folk and classical), but also tension between the selection of digital technologies (downloads, PC, mobile phone and digital formats) and analogue formats or non-technological exchanges (radio, borrows and gifts and buying in the streets). This, we argue, reflects the user/non user dimension of the digital divide (Tsatsou, 2011). The second axis shows differences between individuals with lower educational levels, income and socioeconomic status, who prefer tango, Mexican, hiphop and reggaeton; against preferences for classic, rock and fusion from those individuals higher in the social structural hierarchy. This same tension, is present among individuals who use free alternatives to purchase or listen to music (radio, free internet downloads or simply do not possess any musical work); in contrast to individuals who obtain their music in stores and use physical formats such as $\mathrm{cd} / \mathrm{dvd} / \mathrm{cassette}$. Tension is reflected through musical engagement and appears to be related to the most elemental inclusion/exclusion from technological advancements (Tsatsou, 2011), but also through strategies used to cope with lack of resources to access music. The third axis, relative to musical taste, shows the same differentiation as the second axis, but predominantly consists of differences in musical exchanges: some acquire music from buying it on the streets or copying, whilst others do not possess music or acquire it in stores. This indicates subtle differences between legal and illegal exchanges, a salient aspect that bridges cultural consumption and digital divide research, which requires further investigation.

\section{Discussion and conclusion}

This article, motivated by the need for integrating new analytical dimensions to taste and cultural consumption analysis, explored the relationship between technologies and 
musical taste in Chile. Our analysis focused on bridging a gap between these concepts, understanding them as part of cultural consumption practices. Firstly, we were concerned with how musical exchanges and formats are related to musical taste (RQ1). Our results lead us to conclude that technologies are indeed related, and from our analysis we can derive several important conclusions. Musical taste remains socially stratified following the low-to-highbrow cultural distinction, but modified to account for contemporary contexts (Tampubolon, 2008; Lahire, 2008; Bennett, 2011; Prior, 2013; Leguina, 2015). In the case of Chile, these boundaries appear to be related with different digital divides, a reflection of a society where material differences are much more marked than in more advanced societies. Unfortunately, being this the next step, we were unable to use robust measures of broadness of taste to contrast our findings with theories of cultural omnivourism (Peterson, 2005) and dissonance (Lahire, 2008).

Secondly, to quantify the value that different technological aspects of musical practices have as forms of distinction (RQ2), we applied a multiple factor analysis, which identified three axises? We have found that the first axis of the MFA map shows tension between the selection (or accessibility) of digital and analogic or non-technological modes of acquisition. The second axis contrasts individuals who use online methods to listen to music, measured against individuals that acquire their music in stores or on the streets, with a prominence for physical formats. Interestingly, the third axis shows differences between legal and illegal methods of acquisition. There appears to be consistency between musical genres and practices that different social groups deploy: use of technological advanced methods in younger age groups; use of radio by adults; free media use by groups from lower social positions; use of paid media by higher social positions; and the use of legal or illegal methods depending on consumers' resources and skills. Although these results are specific to the Chilean reality and reflect the characteristics of a particular society, we believe that these still provide tantalising evidence about how complex the relationship between culture and social structure has 
become, and how emerging technologies can reinforce and restructure cultures use in society. Economic and educational barriers to accessing technological goods still represent major obstacles for the Chilean population (perhaps a reflection of all societies), where it is possible to detect positive association between specific taste patterns, exchanges and formats.

Thirdly, comparing the three sub-groups of variables, we believe that musical taste is important, but not the only relevant process of distinction (RQ3). Neither musical preferences nor usage of technologies and different methods to acquire music are products of unified social backgrounds and dispositional sets (Prior, 2013). Yet surprisingly, formats do not seem to offer much explanation; it is modes of exchange which prove to be an emerging property for (technological) distinction. Perhaps it is that methods to acquire and listen to music are associated, and probably one conditions the other. Regardless, we find that beside radio stations and borrows and gifts, it is buying music on the street (piracy) which is the only method of acquisition that implies a monetary transaction related to preferring folk, Mexican, tropical and romantic ballads, music commonly considered in Chile as lowbrow. Similar to Sezneva's (2012) account of accessing music in Russia, this kind of illegal practice is socially accepted and conducted openly in urban areas and markets. Other practices also related to piracy, are free Internet downloads (Bustinza et at, 2013), which appears to be used more frequently by individuals preferring hip-hop, electronic, rock and heavy rock. Access to both practices offer similar outcomes (acquire music cheaper or freely), however they require the deployment of very different resources and skills. A future analysis, testing causal hypotheses regarding the relationship between taste, modes of exchange, and formats (such as the strategy followed by Yaish and Katz-Gerro (2012), to test the relationship between taste and participation) would be an interesting endeavour. 
Thanks to new data and more specific cultural indicators, we are increasingly able to address more elaborated research questions. In recognition of these complexities, it is now necessary to adapt surveys and research methods to integrate these new dimensions to more detailed analysis about the contemporary forms of social distinction. Fifteen years ago very little access to music was through online methods, but this has rapidly changed, with the growth of the internet and social media communities. This growth has also seen cultural boundaries being, in some cases reinforced, in others redefined. Our results indicate that there is an emerging technological cultural capital (Bennett et al, 2009) of music that embraces the Internet, as a process which potentially alters music acquisition and sharing, but also tastes. This ongoing phenomenon is likely to become increasingly influential as symbolic boundaries are drawn, become obsolete and are subsequently redraw in very short time sequences. As our results suggest, the digital divide effectively reinforces musical distinctions. This means that cultural distinctions will increasingly become polarised, as individuals without access to technologies (possession and also been capable to use them adequately) become increasingly marginalised. 


\section{References}

Asociación de Investigadores de Mercado (2013) Actualización grupos socioeconómicos. Available at: comunicaciones.udd.cl/files/2013/05/InformeActualizaci\%C3\%B3n-GSE-2012.pdf (accessed June 20, 2014).

Attewell P (2001) Comment: the first and second digital divides. Sociology of Education 74(3): 252-259.

Bartmanski D and Woodward I (2013) The vinyl: The analogue medium in the age of digital reproduction. Journal of Consumer Culture Epub ahead of print May 31, 2013, doi: $10.1177 / 1469540513488403$.

Bennett T (2011) Culture, choice, necessity: A political critique of Bourdieu's aesthetic. Poetics 39(6): 530-546.

Bennett T, Savage M, Silva EB, Warde A, Gayo-Cal M and Wright D (2009) Culture, Class, Distinction. London: Routledge.

Bull M (2000) Sounding Out the City: Personal Stereos and the Management of Everyday Life. Oxford: Berg.

Bull M (2013) iPod use: an urban aesthetics of sonic ubiquity. Continuum: Journal of Media \& Cultural Studies 27(4): 495-504. 
Bourdieu P (1984) Distinction: A Social Critique of the Judgement of Taste [Translated by Richard Nice]. London: Routledge.

Castells M (2001) The Internet Galaxy: Reflections on the Internet, Business, and Society. Oxford: Oxford University Press.

Chan T W and Goldthorpe J H (2007) Social Stratification and Cultural Consumption: The Visual Arts in England. Poetics 35(2-3): 168-190.

Consejo Nacional de la Cultura y las Artes (2012) Manual del usuario: III encuesta nacional de participación y consumo cultural. Available at: www.cultura.gob.cl/wpcontent/uploads/2013/11/manual-usuario-III-ENPCC-2012.pdf (accessed June 20, 2014).

Crisell A (2002) An Introductory History of British Broadcasting, $2^{\text {nd }}$ Edition. London: Routledge Press, 2002.

Crisell A (2003) More than a music box. Radio cultures and communities in a multimedia world. New York: Berghahn books.

Crossley N and Bottero W (2014) Music worlds and internal goods: The role of convention. Cultural Sociology. Epub ahead of print 15 September 2014. DOI: $10.1177 / 1749975514533209$. 
Daenekindt S and Roose H (2014) Ways of preferring: Distinction through the 'what' and the 'how' of cultural consumption. Epub ahead of print October 10, 2014, DOI: $10.1177 / 1469540514553715$

DiMaggio P (1987) Classification in art. American Sociological Review 52(4): 440-455.

Economic Commission for Latin America and the Caribbean (2003) Los caminos hacia una sociedad de la información en América Latina y el Caribe. Available at: http://www.virtualeduca.org/documentos/2012/cepal_72(2003).pdf (accessed July 15, 2014).

Economic Commission for Latin America and the Caribbean (2011) Social Panorama of Latin America. Available in:

http://www.cepal.org/publicaciones/xml/5/45175/PSE2011-Social-panorama-of-LatinAmerica.pdf (accessed June 20, 2014).

Erickson BH (1996) Culture, class and connections. American Journal of Sociology. 102(1): 217-251.

Escofier B and Pages J (1994) Multiple factor analysis (AFMULT package). Computational Statistics \& Data Analysis 18(1): 121-140.

French-Davis R (1999) Macroeconomía, comercio y finanzas para reformar las reformas en América Latina. Santiago: McGraw-Hill Interamericana. 
Frith S (1996) Performing rites. Evaluating popular music. New York: Oxford University press.

Gans HJ (1999) Popular culture and high culture: An analysis and evaluation of taste. New York: Basic Books.

Gayo M, Teitelboim B and Mendez ML (2009) Patrones culturales de uso de tiempo libre en Chile. Una aproximación desde la teoría Bourdieuana. Revista Universum 24(2): 42-72.

Gonzalez JP (2011) Posfolklore: raíces y globalización en la música popular chilena. ARBOR Ciencia, Pensamiento y Cultura 187(751): 937-946.

Hesmondhalgh D (2009) The digitalisation of music. In: Pratt AC and Jeffcut P (eds) Creativity and Innovation in the Cultural Economy. New York: Routledge, 57-73.

Holt DB (1997) Distinction in America? Recovering Bourdieu's theory of tastes from its critics. Poetics 25(1): 93-120.

Holt DB (1998) Does cultural capital structure American consumption? Journal of Consumer Research 25(1): 1-25.

Instituto Nacional de Estadisticas (2003) Censo 2002: Síntesis de Resultados. Available in http://www.ine.cl/cd2002/sintesiscensal.pdf (accessed July 15, 2014). 
Karmy E (2013) También yo tengo mi cumbia, pero mi cumbia es chilena: apuntes para una reconstrucción sociohistórica de la cumbia chilena desde el cuerpo. Resonancias, 32(1): 93-110.

Keightley K (1996) 'Turn it down!' she shrieked: gender, domestic space, and high fidelity, 1948-59. Popular Music 15(2): 149-177.

Lahire B (2008) The individual and the mixing of genres: Cultural dissonance and selfdistinction. Poetics 36(2-3): 166-188.

Lamont M (1992) Money, morals, and manners: The culture of the French and the American upper-middle class. Chicago: University of Chicago Press.

Lê S, Josse J and Husson F (2008) FactoMineR: An R Package for Multivariate Analysis. Journal of Statistical Software 25(1): 1-18.

Lebaron F (2010) How Bourdieu 'quantified' Bourdieu: The geometric modelling of data. In Robson K and Sanders C (Eds) Quantifying Theory: Pierre Bourdieu. Berlin: Springer, pp.11-29.

Leguina A (2015) Musical distinctions in England: Understanding cultural homology and omnivourism through a methods comparison. Bulletin of Sociological Methodology. Forthcoming. 
Lehtonen T-K (2003) The Domestication of New Technologies as a Set of Trials. Journal of Consumer Culture 3(3): 363-385.

Lizardo O (2008) The question of culture consumption and stratification revisited. Sociologica 2(2). Available at: http://www.sociologica.mulino.it/doi/10.2383/27709

Lizardo O and Skiles S (2012) Reconceptualizing and Theorizing "Omnivorousness": Genetic and Relational. Sociological Theory 30(4): 263-282.

López-Sintas J, Cebollada A, Filimon N and Gharhaman A (2014) Music access patterns: A social interpretation. Poetics 46 (1): 56-74.

López-Sintas J, García-Álvarez ME and Filimon N (2008) Scale and periodicities of recorded music consumption: reconciling Bourdieu's theory of taste with facts. The Sociological Review 56(1): 78-101.

López-Sintas J, Zerva Z and García-Álvarez ME (2012) Accessing recorded music: Interpreting a contemporary social exchange system. Acta Sociologica 55(2): 179-194.

Magaudda P (2011) When materiality 'bites back': Digital music consumption practices in the age of dematerialization. Journal of Consumer Culture 11(1): 15-36.

Magaudda P (2014) The Broken Boundaries between Science and Technology Studies and Cultural Sociology: Introduction to an Interview with Trevor Pinch. Cultural Sociology 8(1): 63-76. 
Mularski JP (2012) Mexican or Chilean: Mexican ranchera music and nationalism in Chile. Studies in Latin American Popular Culture 30(1): 54-75.

NationMaster.com (2014) International statistics at NationMaster.com, International Telecommunication Union, World Telecommunication/ICT Development Report and database, and World Bank estimates. Aggregates compiled by NationMaster. Available at www.nationmaster.com/country-info/stats/Media (accessed June 20, 2014).

Organisation for Economic Co-operation and Development (2013) Crisis squeezes income and puts pressure on inequality and poverty. Available at www.oecd.org/social/soc/OECD2013-Inequality-and-Poverty-8p.pdf (accessed June 20, 2014).

Peterson RA (2005) Problems in comparative research: The example of Omnivorousness. Poetics 33(5/6): 257-282.

Peterson RA and Simkus A (1992) How musical tastes mark occupational status group. In: Lamont $\mathrm{M}$ and Fournier $\mathrm{M}$ (eds) Cultivating Differences. Chicago: University of Chicago Press.

Pinch T and Bijsterveld K (2004) Sound Studies: New Technologies and Music. Studies of Science 34(5): 635-648. 
Pinch T and Trocco F (2004) Analog Days: The Invention and Impact of the Moog Synthesizer. Cambridge: Harvard University Press.

Prieur A and Savage M (2013) Emerging forms of cultural capital. European Societies 15(2): 246-267.

Prior N (2013) Bourdieu and the Sociology of Music Consumption: A Critical Assessment of Recent Developments. Sociology Compass 7(3): 181-193.

Prior N (2014) The plural iPod: A study of technology in action. Poetics 42(1): 22-39.

R Core Team (2013) R: A Language and Environment for Statistical Computing. Vienna: Foundation for Statistical Computing.

Reckwitz A (2002) Toward a theory of social practices: A development in culturalist theorizing. European Journal of Social Theory 5(2): 243-263.

Rivera PR (2011) 'Tropical Mix': Afro-Latino space and Notch's reggaetón. Popular Music and Society 34(2): 221-235.

Roose H and Stichele AV (2010). Living room vs. concert hall: Patterns of music consumption in Flanders. Social Forces 89(1): 185-208.

Rössel J (2011) Cultural capital and the variety of modes of cultural consumption in the opera audience. The Sociological Quarterly 52: 83-103. 
Schatzki T (1996) Social Practices: A Wittgensteinian Approach to Human Activity and the Social. Cambridge: Cambridge University Press.

Sezneva O (2012) The pirates of Nevskii Prospekt: Intellectual property, piracy and institutional diffusion in Russia. Poetics 40(2): 150-166.

Sterne J (2003a) Bourdieu, technique and technology. Cultural studies, 17(3/4): 367389.

Sterne J (2003b) The Audible Past: Cultural Origins of Sound Reproduction. Durham: Duke University Press.

Sterne J (2012) MP3: The Meaning of a Format. Durham: Duke University Press.

Tampubolon G (2008) Distinction in Britain, 2001-2004?. European Societies 10(3): 403-428.

Taylor T, Katz M and Grajeda T (eds) (2012) Music, Sound, and Technology in America: A Documentary History of Early Phonograph, Cinema, and Radio. Durham: Duke University Press.

Tepper S and Hargittai E (2009) Pathways to Music Exploration in a Digital Age. Poetics 37(1): 227-249. 
Torche F (2007) Social status and cultural consumption: The case of reading in Chile Poetics 35(2/3): 70-92.

Torche F (2010) Social status and public cultural consumption: Chile in comparative perspective. In Chan TW (ed). Social status and cultural consumption. Cambridge: Cambridge University Press.

Tsatsou P (2011) Digital divides revisited: what is new about divides and their research? Media, Culture \& Society 33(2): 317-331.

van Dijk JAGM (2006) Digital divide research, achievements and shortcomings. Poetics 34(4-5): 221-235.

Van Dijk JAGM (2008) One Europe, digitally divided. In Chadwick A and Howard PN (eds) Routledge Handbook of Internet Politics. New York: Routledge.

Van Rees K, Vermunt J and Verboord M (1999) Cultural Classifications under Discussion: Latent Class Analysis of Highbrow and Lowbrow Reading. Poetics 26(5-6): $349-365$.

Viollier P (2013) Análisis crítico de los mecanismos para la medición de piratería de software: El caso particular del 'Global Software Piracy Study'. Available at: https://www.derechosdigitales.org/wp-content/uploads/Art\%C3\%ADculo-BSA.pdf. (accessed June 20, 2014). 
Warde A (2005) Consumption and Theories of Practice. Journal of Consumer Culture 5(2): 131-153.

Warde A (2011) Dimensions of a social theory of taste. In Warde A (ed) Cultural consumption, classification and power. Oxon: Routledge.

Warde A (2014) After taste: Culture, consumption and theories of practice. Journal of Consumer Culture 14(3): 279-303.

Wright D (2011) Making tastes for everything: Omnivorousness and cultural abundance. Journal for Cultural Research 15(4): 355-371.

Yaish M and Katz-Gerro T (2012) Disentangling 'Cultural Capital': The Consequences of Cultural and Economic Resources for Taste and Participation. European Sociological Review 28(2): 169-185. 